Dunamis: Jurnal Teologi dan Pendidikan Kristiani

Volume 3, Nomor 1 (Oktober 2018)

ISSN 2541-3937 (print), 2541-3945 (online)

http://www.sttintheos.ac.id/e-journal/index.php/dunamis

Submitted: 22 Oktober 2018

Accepted: 21 November 2018

Published: 30 November 2018

\title{
Peranan Kejawen dan Islam dalam Praktik Ziarah serta Upacara Labuhan di Parangkusuma, Yogyakarta
}

\author{
Pramadi Tjahjono \\ Fakultas Theologi Universitas Kristen Surakarta \\ pramaditjahjono@yahoo.co.id
}

\begin{abstract}
The relation between Islam and Javanese tradition is seen at a case of a pilgrimage and ritual of Labuhan at a beach of Parangkusuma, Yogyakarta. This ritual is well-known, and even became a tourism agenda, so is tha pilgrimage. The legend of a myth character like Kanjeng Ratu Kidul was engaged firmly with the kings and citizens of Mataram, specially Yogyakarta palace. In the ritual of Labuhan and pilgrimage (usually holds on Tuesday and Kliwon of Friday) in Parangkusuma showed two interested phenomenons about Islam and Kejawen interaction. There was an opinion that Islam and Kejawen interaction is a parallelism. This article used a descriptive method to explain that phenomenon. The conclusion is, the relation occurred in the practice of ritual of Labuhan and pilgrimage is a parallelism, what brought a certain understanding about Javanese, spesifically in relation with religion.
\end{abstract}

Keywords: Labuhan; pilgrimage; Parangkusuma beach; Islam; Javanese; parallelism

\begin{abstract}
Abstrak
Hubungan Islam dan Kejawen terlihat pada kasus perziarahan dan upacara labuhan di pantai Parangkusuma, Yogyakarta. Upacara labuhan cukup dikenal banyak orang bahkan menjadi agenda wisata untuk menarik wisatawan, demikian pula perziarahan. Legenda tentang tokoh mitos Kanjeng Ratu Kidul sangat erat hubungannya dengan para raja dan rakyat Mataram, khususnya keraton Yogyakarta. Dalam upacara labuhan dan perziarahan (yang biasanya dilakukan pada setiap malam Selasa dan Jumat Kliwon) di Parangkusuma memperlihatkan fenomena yang menenarik untuk melihat interaksi yang terjadi antara Islam dan Kejawen. Ada pendapat yang mengatakan bahwa interaksi yang terjadi antara Islam dan Jawa pada perhelatan tersebut adalah sebuah parallelisme. Artikel ini menggunakan metode deskriptif pada fenomena yang ada di Parangkusuma Kesimpulannya adalah, interaksi yang terjadi merupakan sebuah parallelisme, yang membawa pemahaman tertentu tentang Jawa, khususnya dalam hubungan dengan agama.
\end{abstract}

Kata kunci : ziarah; pantai Parangkusuma; Kejawen; paralelisme 


\section{PENDAHULUAN}

Orang Jawa Tengah mempunyai kepercayaan tentang pertolongan dari rohroh leluhur dengan cara berkomunikasi dengan roh-roh tersebut di tempat-tempat yang dianggap keramat/gaib. Tradisi ziarah tidak hanya mengunjungi makam leluhur saja, namun dilakukan juga di tempattempat yang dianggap wingit atau gaib. Tempat yang dianggap keramat atau gaib biasanya makam orang-orang ternama yang dianggap memiliki kesaktian (kasekten), tempat peninggalan (petilasan) dari seseorang yang sakti, tempat angker yang dipercaya dihuni oleh roh halus, biasanya mata air/sendang atau pohon besar/batu besar.

Ziarah yang dilakukan di Parangkusumo, tepatnya di Kecamatan Kretek, Kabupaten Bantul, Daerah Istimewa Yogyakarta, terletak di suatu pantai dari Samudra Indonesia yang dalam dengan ombak yang besar. Parangkusumo adalah tempat pertama kalinya Panembahan Senopati bertemu dengan Kanjeng Ratu Kidul ketika ia meminta pertolongan untuk dapat naik tahta. Selain itu Parangkusumo juga merupakan pintu gerbang keraton Kanjeng Ratu Kidul di Samudra Indonesia.

Mereka yang terlibat dalam upacara labuhan adalah para puteri kerabat Keraton yang sudah tua usianya, abdi dalem
Keparak, abdi dalem Kawedanan Ageng Punakawan Widyabudaya dan Kyai Penghulu pada persiapan yang bersifat tertutup. Kemudian pelaksanaan upacara labuhan bersifat terbuka artinya dilakukan di luar Kraton sampai di tempat di mana dilaksanakan upacara tersebut yang melibatkan abdi dalem Kawedanan Ageng Punakawan Widyabudaya dan pejabat di luar sekitar tempat upacara.

Ziarah yang dilakukan di Parangkusuma, biasanya dilakukan pada hari Selasa dan Jumat Kliwon.Perziarahan biasanya dimulai sekitar pukul 19.00 dan semakin ramai menjelang tengah malam. Para peziarah lebih dahulu membeli satu bungkus bunga yang akan dipersembahkan kepada Kanjeng Ratu Kidul dan Panembahan Senopati. Bungkusan bunga berisi bunga mawar merah dan putih, melati dan bunga kantil, biasanya yang masih kuncup dan sebungkus kecil kemenyan. Para peziarah masuk ke dalam cepuri di Parangkusuma dan menghaturkan bungkusan yang berisi bunga dan kemenyan tadi kepada juru kunci. Juru kunci bersama dengan peziarah duduk di hadapan dua buah gundukan batu. Setelah juru kunci menghantarkan lewat doa, bungkusan kembang dilewatkan di atas api pedupaan dan kemudian peziarah diminta untuk memohon sendiri kepada Kanjeng Ratu Kidul dan Panembahan Senopati dengan 
menaburkan bungkusan kembang di salah satu atau kedua gundukan batu yang ada di cepuri dan sebelumnya memberikan sedikit uang kepada juru kunci.

Peziarah kemudian berlutut di hadapan selo gilang dan memanjatkan doa, antara lain doa Al-Fatihah yang dilanjutkan dengan permohonannya dengan bahasa Jawa Krama memohon bantuan dari Kanjeng Ratu Kidul dan Panembahan Senopati untuk membantunya mendapatkan apa yang menjadi keinginannya. Bungkusan bunga lalu ditaburkan di selo gilang, ada sebagian yang kemudian dibawa ke tepi laut dan ditaburkan ke laut. Peziarah yakin bahwa setelah bunga ditaburkan, bagi mereka yang berhasil mendapatkan bunga kantil yang masih kuncup merupakan berkat dari Kanjeng Ratu Kidul atau Panembahan Senopati sebagai bukti permohonan mereka telah dikabulkan. Bunga kantil yang didapatkan kemudian disimpan di tempat di mana pemohon sangat mengharapkan berkat dan dipakai sebagai azimat.

\section{Faktor Ekonomi}

Kepercayaan orang Jawa tentang keberadaan roh-roh halus tidak hanya berhubungan dengan keselamatan, melainkan juga roh-roh tersebut dapat dimintai pertolongan untuk mewujudkan apa yang menjadi keinginannya. Seperti yang dikatakan oleh Clifford Geertz, berkenaan dengan bantuan yang datang dari para makhluk halus untuk menolong manusia dalam memenuhi kebutuhan ekonomi contohnya adalah tuyul (yang berujud seorang bocah kecil dan telanjang dengan tugas mencuri uang), gebleg (berbentuk ayam dan biasanya mencuri padi). ${ }^{1}$

Danyang (para penunggu desa yang dianggap sebagai roh dari asal-muasal desa tersebut, juga dapat dimintai pertolongan, baik berkenaan dengan keselamatan desa ataupun untuk keperluan yang lainnya. Akan tetapi di dalam mencari bantuan yang berasal dari para roh-roh halus, mereka juga takut disebut shirk (menduakan Tuhan Allah dalam ajaran Islam). Oleh karena itu, sebagian besar mereka pergi ke suatu tempat yang wingit dan dipercaya bahwa roh penghuni atau arwah (yang meninggal atau karena suatu peristiwa tertentu) di tempat tersebut, dapat memberikan apa yang menjadi permohonannya dan terhindar dari sebutan shirk karena tempat tersebut dianggap sebagai sebuah tempat perziarahan yang sudah "diakui" oleh umum (dalam hal ini secara eksplisit menunjukkan adanya "pengakuan" agama atas keberadaan tempat tersebut). Seperti yang terjadi di tempat-tempat perziarahan, seperti di Parangkusumo dari sebagian yang

${ }^{1}$ Clifford Geertz, Abangan, Santri Dan Priyayi Dalam Masyarakat Jawa (Jakarta: Pustaka Jaya, 1981), 6 . 
diwawancarai menyatakan bahwa hal tersebut bukanlah shirik karena permohonan yang disampaikan dialamatkan kepada Allah melalui perantara yaitu Kanjeng Ratu Kidul dan Panembahan Senopati.

\section{Faktor Sosio Budaya}

Orang Jawa dikenal sebagai seorang yang toleran terhadap sesuatu yang baru. Berdasarkan pada prinsip harmoni yang ada dalam pemahaman/pandangan hidup orang Jawa, sesuatu yang dianggap asing tidak dipandang sebagai yang mengancam melainkan dapat diadopsi yang pada akhirnya memperluas pandangan hidup orang Jawa. Prinsip tersebut memungkinkan masuknya pengaruh-pengaruh asing ke dalam kebudayaan Jawa tanpa mengalami pertentangan melainkan dengan sedemikian rupa dianggap bagian dari kehidupannya.Keberadaan Kanjeng Ratu Kidul dihubungkan dengan keberadaan wahyu dan kasekten. Perpaduan antara dua budaya (Islam dan Jawa) tersebut sangat harmonis dalam arti keduanya saling mengisi dan memberi arti sehingga tercaipta sebuah budaya "baru". Hal ini mungkin menjadi salah satu faktor yang mengisi pemahaman Jawa tentang pengabulan doa dengan menganggap Kanjeng Ratu Kidul dan Panembahan Senopati sebagai orangorang yang dikasihi Allah sama seperti kedudukan dari para wali.

\section{Faktor Keagamaan}

Pemahaman keberadaan tentang orangorang tertentu yang disebut wasilah (mereka yang dikasihi Allah oleh karena jasanya selama ia hidup bagi agama Islam) bukan hanya penghormatan atas kebesaran jasanya bagi agama Islam saja, akan tetapi dipercaya juga sebagai orang-orang yang dekat dengan Allah. Atas kedekatannya inilah, orang Islam tersebut percaya bahwa setiap doa permohonan yang dipanjatkan melalui perantara para wasilah, ada keyakinan bahwa doa yang dipanjatkan pasti dikabulkan. Penghormatan yang begitu besar atas keberadaanorang-orang ini menciptakan pemahaman tentang adanya perantara bagi doa-doa manusia yang disampaikan kepada Allah. Permohonan yang disampaikan tidak hanya melalui nama mereka, akan tetapi melalui peninggalan atau makam di mana para "kekasih Allah" itu dimakamkan atau di tempat di mana sebuah peristiwa penting yang terjadi atas orang tersebut (para wasilah). Dalam praktek ziarah dan labuhan di Parangkusuma, Mark Woodward mengatakan bahwa "laku" yang dipraktekkan di Parangkusuma adalah "tapa" untuk mendapatkan "kasekten" (kesaktian) yang disamakan dengan sembahyang "zuhud" (asketisisme) di mana 
seseorang bermeditasi dan memfikuskan diri hanya kepada Allah. ${ }^{2}$

\section{METODOLOGI}

Metode yang digunakan dalam penelitian ini adalah metode deskriptif analisis dengan pendekatan fenomenologis. Pendekatan fenomenologi merupakan pendekatan untuk melihat peristiwa, tidak hanya dilakukan dari segi sejarahnya, melainkan juga dari apa yang dinampakkan atau yang dihadirkan bagi kita saat ini dan membandingkannya. Fenomena-fenomena dipaparkan dan kemudian dianalisa untuk melihat hal yang sebenarnya terjadi di balik penampakan fenomenologis dalam kasus perziarahan dan labuhan di pantai Parangkusuma. Proses penganalisaan dilakukan dengan dibantu literatur, wawancara dan pengamatan. Dalam proses tersebut, khususnya literatur dengan menggunakan teori-teori dari beberapa ahli yang telah melakukan penelitian tentang keberadaan Islam di Jawa.

Mark Woodward mengatakan bahwa apa yang ada pada masyarakat Jawa sekarang merupakan pengaruh dari Islam. Demikian juga dengan Geertz yang mengatakan bahwa kebudayaan dan kehidupan Jawa merupakan pengaruh dari agama Hindu. Apa yang terjadi pada kehidupan masyarakat Jawa merupakan

\footnotetext{
${ }^{2}$ Mark Woodward, Islam Jawa (Yogyakarta: LKIS, 1989), 4
}

interaksi dari pengaruh-pengaruh asing yang masuk. Akan tetapi apakah bentuk interaksi antara Jawa dengan pengaruhpengaruh asing senantiasa terjadi sebuah sinkretis atau sintesa saja? Menurut Olaf Schumann, interaksi yang ada pada kehidupan keagamaan masyarakat Jawa juga terjadi suatu parallelisme, artinya antara yang satu dan yang lainnya berjalan bersama-sama tanpa saling mempengaruhi dan keduanya dapat diterima secara luas dalam masyarakat.

Fenomena yang dinampakkan di Parangkusuma (baik labuhan maupun ziarah), terlihat adanya unsur Islam dalam aktivitas keagamaan yang dimunculkan. Unsur itu dinampakkan dengan keberadaan masjid, pembacaan Al-Fatihah pada pembukaan doa. Dalam upacara labuhan dan ziarah di Parangkusuma, juga terdapat unsur-unsur Hinduisme, seperti yang dinampakkan pada tokoh mitos Kanjeng Ratu Kidul, tapa. Kepercayaan akan makhluk halus (seperti halnya kepada Kanjeng Ratu Kidul) yang mendiami sebuah tempat tertentu (disebut punden) sangat kuat di kalangan orang Jawa, khususnya yang dimasukkan ke dalam golongan abangan. Menurut Geertz, dalam upacara labuhan serta ziarah yang ada di Parangkusuma memperlihatkan unsur-unsur Hindu, seperti halnya penghormatan kepada 
Kanjeng Ratu Kidul dan tempat serta pemahaman hari-hari yang sakral. ${ }^{3}$

Baik pengaruh Islam, ataupun Hindu dinampakkan dalam praktek ziarah serta upacara labuhan di Parangkusuma. Kedua unsur ini secara jelas terlihat dari praktik yang ada, khususnya yang dilakukan oleh para peziarah pada waktu yang bersamaan. Ketika seseorang memohon berkat kepada Allah melalui berkat Kanjeng Ratu Kidul, ia juga percaya bahwa Kanjeng Ratu Kidul memberikan berkat kepadanya. Hal ini dinampakkan melalui doa-doa yang diucapkan baik yang bernafaskan Islam dengan menyebut nama Allah serta pembacaan surat Al-Fatihah ataupun dengan permohonan yang disampaikan kepada Kanjeng Ratu Kidul. Apakah yang terjadi di Parangkusuma, baik upacara labuhan ataupun praktek ziarah merupakan sebuah sinkretisme ataukah sebuah sintesa atau juga parallelisme?

\section{Sinkretisme}

Sinkretisme dalam bagian ini merupakan penggabungan dua buah budaya/ tradisi dengan mengambil unsurunsur yang baik dari dua tradisi tersebut dan membentuknya menjadi sebuah tradisi yang baru. Contoh dari sinkretis ini terjadi pada ajaran Pangestu (Paguyuban Ngesti Tunggal) yang tertulis dalam kitab

\footnotetext{
${ }^{3}$ Geertz, Abangan, Santri Dan Priyayi Dalam Masyarakat Jawa.
}

Sasangka Jati. Kenyataan yang ada pada upacara labuhan dan ziarah di Parangkusuma adalah sebuah pertemuan dua tradisi yang berbeda, yaitu Islam dan Kejawen (dengan latar belakang Hindu). Yang menarik pada fenomena keagamaan pada upacara labuhan dan ziarah di Parangkusuma adalah baik unsur Islam maupun Hindu dinampakkan.

\section{Sintesa}

Sintesa adalah perpaduan antara dua hal yang berbeda (tesis dan anti tesis) yang keduanya dilebur menjadi sesuatu yang baru (sintesis). Perpaduan ini (sintesa) merupakan usaha untuk mengadopsi keduanya dan dicampur menjadi satu dalam sebuah pengertian yang tunggal (bukan pengertian yang baru). Praktek ziarah dan upacara labuhan di Parangkusuma memperlihatkan kepada kita adanya pertemuan antara Islam dan Kejawen. Yang terjadi di Parangkusuma adalah pertemuan antara keduanya baik Islam maupun Kejawen dalam sebuah kesatuan waktu dan pelaku. Sangatlah sulit untuk memastikan apakah praktik keagamaan yang terjadi sama dengan yang terjadi pada Siwa-Budha, yaitu keduanya membaur dan diidentifikasikan sebagai sebuah kebenaran tunggal. Pembauran yang terjadi atas SiwaBudha membentuk sebuah keselarasan yang baru. 


\section{Parallelisme}

Parallelisme adalah dua buah budaya atau tradisi yang dilakukan pada waktu yang bersamaan, akan tetapi kedua budaya itu tetap pada identitasnya masing-masing. Fenomena yang dinampakkan di Parangkusuma, baik upacara labuhan dan ziarah ke petilasan Panembahan Senopati dan Kanjeng Ratu Kidul menunjukkan adanya dua buah tradisi yang berinteraksi dan berjalan bersama-sama.

Unsur dari Islam atas labuhan dan ziarah di Parangkusuma, terlihat dengan adanya bangunan masjid yang digunakan sebagai salah satu tempat menunggu wisik. Demikian juga dengan pengucapan $\mathrm{Al}$ Fatihah dalam memanjatkan doa, serta pemahaman barakah melalui wasilah para auliya (kekasih Allah). Keberadaan Kanjeng Ratu Kidul sebagai wasilah memang masih dalam sebuah perdebatan. Namun konsep ini dapat dikaitkan dengan pemahaman tentang jin, di mana keberadaan jin (sebagai salah satu makhluk yang dekat dengan Allah) dapat saja menjadi wasilah.

Demikian juga unsur Kejawen, dinampakkan dalam aktivitas keagamaan di Parangkusuma. Unsur itu Nampak pada pemahaman yang terdapat dari simbolsimbol yang ada, seperti tentang kuncup bunga kanthil, air laut, malam Selasa dan Jumat Kliwon, pembakaran dupa atau kemenyan, serta posisi tubuh. Kecuali penampakan seperti yang terdapat dalam simbol-simbol, pemahaman tentang "laku" di dalam meraih cita-cita juga dinampakkan yang menjadikan keseriusan para pelaku upacara dan peziarah di dalam melakukan aktivitas keagamaannya.

Kedua pemahaman dan bentuk lahir (hal yang dinampakkan) dalam upacara labuhan dan ziarah di Parangkusuma, baik Islam maupun Kejawen dilakukan secara bersama-sama pada saat yang sama. Keduanya berkembang dan diterima seperti yang dinampakkan dalam tradisi labuhan dan ziarah. Jikalau kita melihat definisi parallelisme, dapat dipahami sebagai suatu kesejajaran yang tanpa dapat bertemu. Akan tetapi dalam pemahaman sosiologis, hal itu dimungkinkan terjadi suatu "kerjasama" yang merupakan titik persinggungan.

Seperti yang diungkapkan di atas, parallelisme tidak hanya merupakan kesejajaran yang tidak dapat bertemu, akan tetapi dimungkinkan terjadinya suatu pertemuan. Pertemuan yang dimaksud di sini bukanlah seperti dua buah rel kereta api yang menjadi satu, akan tetapi pertemuan yang dimaksud adalah suatu tindakan atas dua tradisi yang berbeda dalam satu waktu yang bersamaan. 
ANALISIS DAN HASIL

\section{Unsur-unsur dalam Upacara Labuhan dan Ziarah}

Jikalau pemakaian tradisi di dalam rangka dakwah Islam maka tentunya unsur Islam yang lebih kuat terhadap budaya Jawa. Pada kasus Parangkusuma yang ada di dalam upacara labuhan dan perziarahan, fenomena yang dinampakkan memperlihatkan adanya pengaruh tradisi agama Islam. Pengaruh tersebut dinampakkan dalam doa-doa yang dipanjatkan yang lebih dahulu membaca surat Al-Fatihah yang diikuti permohonan doa dengan menggunakan bahasa Jawa. Selain itu dalam kompleks Parangkusuma didirikan sebuah bangunan masjid yang bernama Al-Darus Salam.

Tokoh mitos Kanjeng Ratu Kidul muncul dalam latar belakang agama Hindu dan demikian juga dengan Panembahan Senopati dalam unsur kejawen. Para auliya dalam Islam adalah mereka yang dekat dengan Allah karena perbuatan semasa hidupnya. Jikalau hal tersebut dihubungkan dengan kedua tokoh di atas sulit mendapatkan hubungan antara tokoh Kanjeng Ratu Kidul dan Panembahan Senopati sebagai wassilah. Dari hasil wawancara, pada umumnya para peziarah mengatakan bahwa keberadaan tokoh mitos Kanjeng Ratu Kidul dianggap sebagai wassilah dan bukan roh atau setan yang bertentangan dengan Allah.

Dari cerita tentang Panembahan Senopati yang mencari wahyu Allah dan mengasingkan diri di pantai Selatan menunjukkan bahwa perziarahan kepada Kanjeng Ratu Kidul sudah ada sebelumnya. Tradisi ini selanjutnya diisi dengan unsurunsur Islami sehingga terlihat sebagai yang Islami. Unsur-unsur tersebut Nampak pada pemahaman tentang tujuan dan pengabulan doa yang dari Allah dan bacaan-bacaan baik dari Al-Qur'an maupun doa-doa yang memakai bahasa Arab. Sesuatu yang sudah ada yang kemudian dikemas menjadi Islam menunjukkan adanya unsur Islam. Banyak di antara orang Islam sendiri yang mengatakan bahwa tindakan memohon bantuan dari para roh-roh adalah perbuatan yang mushirk termasuk di dalamnya memohon kepada Kanjeng Ratu Kidul. Doa-doa yang diucapkan biasanya diawali dengan bacaan dari surat Al-Fatihah atau juga dengan mengucapkan shahadat. Doadoa kemudian dilanjutkan dengan permohonan kepada Kanjeng Ratu Kidul atau Panembahan Senopati.

Surat Al-Fatihah memang mempunyai posisi yang penting dalam pemahaman Islam. Surat Al-Fatihah dikenal sebagai “Ummu'l-Qur'an" (induk Al-Qur'an) atau "Ummu'l-Kitab" (induk Alkitab) karena dia merupakan induk bagi semua isi Al-Qur'an 
serta menjadi intisari dari kandungan AlQur'an, dan karena itu diwajibkan membacanya pada tiap-tiap shalat. Berdasarkan pengertian ini maka setiap doa senantiasa diawali oleh pembacaan $\mathrm{Al}$ Fatihah, demikian pula yang terjadi di Parangkusuma.

Dinas Pariwisata memang membangun masjid Al-Darus Salam untuk keperluan ibadah sebagai sarana pelengkap pariwisata. Yang terjadi di Parangkusuma, seperti yang diungkapkan oleh Siswanto, seorang peziarah, setelah ia melakukan persembahan bagi Kanjeng Ratu Kidul dengan menabur bunga yang telah didoakan oleh Juru Kunci, ia tidur di masjid Darus Salam. Siswanto tidur di masjid bukan sekadar untuk menghilangkan kelelahan, melainkan untuk mendapatkan "wisik"4 atas apa yang diminta kepada Kanjeng Ratu Kidul.

\section{Pandangan Tentang Ekonomi dalam Ziarah di Parangkusuma}

Orang Jawa memahami tentang berkat Tuhan tidak hanya didapat dari kerja keras saja, melainkan juga atas takdir dan pertolongan "Tuhan". Ungkapan nrima ing pandum (menerima atas jatah/pemberian) adalah sebuah ungkapan yang menunjukkan bahwa apa yang diterimanya hanyalah

\footnotetext{
${ }^{4}$ Wisik adalah wahyu sebagai tanda dari Allah melalui suara atau mimpi sebagai jawaban atau tanda bagi orang yang sedang memohonkan sesuatu.
}

karena pemberian Tuhan atas takdir yang sudah ditentukan bagi dirinya. Meskipun percaya bahwa rejeki/berkah Tuhan yang diberikan pada dirinya sudah ditakdirkan lebih dahulu, ini bukan berarti ia hanya tinggal menunggu pemberian Tuhan.

Setiap makhluk telah dibagi nasibnya, ditarik garis kehidupannya, dan tidak dapat menyeleweng daripadanya. Justru karena itu, orang yang mengerti tidak akan berusaha untuk mengadakan perubahanperubahan pada jalannya dunia dan kehidupan. Membuat rencana-rencana besar untuk memperbaiki dunia dan berusaha untuk melaksanakannya tanpa memperhatikan masyarakat dan kosmos merupakan tanda kesombongan karena kekuasaan untuk merubah segala sesuatu dalam realitas tidak terletak di tangan manusia. Cara untuk menerobos keterikatan total individu dari struktur-struktur masyarakat adalah melalui wahyu, di mana ia dipanggil untuk melakukan perbuatanperbuatan yang luar biasa.

Panggilan semacam itu memperlihatkan diri dengan cara yang luar biasa juga, misalnya melalui mulut seorang resi atau melalui penampakan cahaya biru (Jawa: ndaru). Biasanya panggilan itu (wisik) terjadi apabila nasib memilih seseorang untuk melakukan tindakantindakan luar biasa dalam masyarakat.Siapa yang menerima panggilan itu berhak untuk 
melakukan tindakan-tindakan yang bertentangan dengan adat-istiadat, tata karma tradisional, dengan rukun dan sikap hormat. $^{5}$

Setelah memanjatkan doa permohonan kepada Allah melalui Panembahan Senopati dan Kanjeng Ratu Kidul, peziarah menunggu "jawaban" dari permohonan itu dengan "tidur" di cepuri atau di bagian lain dari Parangkusuma untuk mendapatkan petunjuk/wisik dari Kanjeng Ratu Kidul. Permohonan-permohonan yang dipanjatkan melalui doa biasanya berhubungan dengan "pelarisan" atau permohonan untuk mendapat pangkat lebih tinggi, bahkan dalam mencalonkan diri menjadi lurah. Berdasarkan pemahaman tentang ini (wisik/ndaru) orang Jawa (peziarah) percaya bahwa apa yang dilakukannya dapat "merubah" takdir yang pada akhirnya dengan bantuan dan berkah dari Panembahan Senopati serta Kanjeng Ratu Kidul, ia dapat mendapatkan apa yang menjadi permohonannya.

Permohonan tersebut adalah usaha untuk mengubah garis nasib yang ada pada dirinya, meskipun dengan cara yang "melanggar" tradisi yang ada dan mungkin mengganggu ketenteraman masyarakat, akan tetapi dengan cara tersebut tidaklah mengganggu keseimbangan kosmos dan

\footnotetext{
${ }^{5}$ Djaka Soetapa, ed., Lima Titik Temu AgamaAgama (Yogyakarta: Duta Wacana University Press, 2000), 154.
}

bahkan harus dijalani karena hal tersebut sudah mendapat "ijin" dari kosmos.

\section{Pemahaman tentang Laku}

"Laku" dalam pemahaman Jawa adalah suatu proses sepanjang masa, mencakup seluruh kejadian, dari mana asal mula dank e mana arah tujuannya ${ }^{6}$. Manusia melakukan "laku" sebagai usaha untuk mencapai kesempurnaan hidup yang menuju pada bersatunya manusia dengan Tuhan. Sunan Kali Jaga mengartikan "laku" sebagai cara untuk mengerti akan makna hidup dan cara untuk kembali kepada asal dari manusia. Laku sebagai proses manusia kembali kepada asalnya yang dimulai semenjak ia ada di dunia dengan diawali dengan kesadaran dan pengertian akan asalmuasalnya. Pandangan yang diberikan oleh R.Ng. Ranggawarsita adalah proses pemahaman diri melalui pencegahan hawa nafsu untuk mencapai tingkatan manusia yang sejati, yaitu tahu akan jati dirinya. Laku adalah usaha manusia untuk mencapai apa yang diharapkannya yaitu manunggaling kawula-Gusti (bersatunya manusia dengan Tuhan) sebagai wujud dari pengetahuan sejati tentang keberadaan manusia. Yang terjadi di Parangkusuma adalah sebagian dari para peziarah datang ke sana untuk bersemedi mendapatkan

\footnotetext{
${ }^{6}$ Damarjati Supajar, Kedudukan "Laku” Dalam Rangka Pandangan Hidup Orang Jawa (Yogyakarta: Yayasan Ilmu Pengetahuan dan Kebudayaan Panunggalan, 1998), 2.
} 
pengetahuan sejati, akan tetapi kebanyakan dari mereka menjalankan laku untuk mendapatkan apa yang menjadi keinginannya.

Menurut pemahaman dari pujanggapujangga di atas (Raden Ngabehi Ranggawarsita, Sunan Kali Jaga, Gusti Mangkunegara IV) laku diartikan sebagai tindakan manusia untuk mengetahui identitas sebenarnyadari keberadaannya. Manusia yang merupakan bagian dari Gusti dan akan kembali kepadanya sebagai tempat dari asal-muasalnya. Pergeseran yang terjadi adalah pemahaman tentang kembalinya manusia kepada asalmuasaldipahami dengan persekutuan manusia-Tuhan dengan terkabulnya permohonan. Kehidupan manusia sudah digariskan oleh Tuhan dan dengan pertolongan Tuhan melalui para perantara manusia dapat mengubah takdir itu. Maka pemahaman tentang laku dimengerti sebagai usaha manusia untuk mengubah takdir dengan melakukan cara-cara tertentu di antaranya adalah dengan samadi/tapa.

\section{Simbolisme dalam Praktek Ziarah}

Kehidupan orang Jawa dilingkupi oleh mitos dan simbol-simbol. Bentuk-bentuk simbolisme dalam budaya Jawa sangat dominan dalam segala hal dan dalam segala bidang. Bentuk-bentuk simbolis itu dapat dikelompokkan dalam tiga macam tindakan simbolis yaitu pertama, tindakan simbolis dalam religinya; kedua tindakan simbolis dalam tradisinya; dan ketiga tindakan simbolis dalam keseniannya. Lebih lanjut Budiono Herusatoto mengatakan bahwa tindakan simbolis dalam religi sebagai sisa peninggalan jaman mitos yaitu pemberian sesaji atau sesajen bagi sing mbahureksa, mbahe atau danyang yang berdiam di pohon-pohon beringin atau pohon-pohon besar dan telah berumur tua, di sendangsendang atau belik, tempat mata air, di kuburan-kuburan tua dari tokoh-tokoh yang terkenal pada masa lampau, atau tempattempat lainnya yang dianggap keramat dan mengandung kekuatan gaib atau angker dan wingit atau berbahaya. ${ }^{7}$ Tindakan simbolis yang berhubungan dengan kesatuan roh leluhurnya itu nampak dalam tindakan sesaji, menyediakan bunga, membakar kemenyan, menyediakan air putih, selamatan, ziarah.

Di satu sisi, memang terlihat adanya unsur-unsur yang berasal dari Islam dalam upacara labuhan atau ziarah di Parangkusuma. Unsur-unsur Islam itu dinampakkan dalam doa Al-Fatihah dan pemahaman akan Allah yang memberikan berkat melalui wassilah Kanjeng Ratu Kidul. Akan tetapi, di sisi lain, kita melihat akan adanya unsur Kejawen terhadap

\footnotetext{
${ }^{7}$ Y. Argo Twikromo, Ratu Kidul (Yogyakarta: Yayasan Bentang Budaya, 2000), 100.
} 
pemahaman Islam yang ada pada upacara labuhan dan ziarah di Parangkusuma, seperti halnya pemahaman tentang perantara atau mereka yang dikasihi Allah di mana tokoh mitos Jawa yang berlatarbelakangkan Hinduisme yaitu Kanjeng Ratu Kidul dimasukkan menjadi salah satu wasilah Allah. Di pihak lain, kita dapat melihat unsur-unsur dari keduaduanya dan "bercampur" menjadi satu, seperti dalam doa yang dipanjatkan di mana peranan surat Al-Fatihah dan Kanjeng Ratu Kidul menjadi penting dalam pengabulan doa.

\section{Kuncup Bunga Kanthil}

Satu paket bunga persembahan terdiri dari kelopak bunga mawar merah dan putih, bunga melati baik yang kuncup maupun yang sudah mekar dan ditambah satu atau dua kuncup bunga kanthil serta satu plastik kecil kemenyan yang ditempatkan pada bungkus dari daun pisang. Menurut keterangan dari bapak Surono Jumadi, seorang juru kunci di Parangkusuma, bunga kanthil (kuncup bunga kanthil) mempunyai makna sebagai simbol penolak bala. ${ }^{8}$ Ia menambahkan bahwa yang mempunyai daya untuk menolak bala adalah kuncup bunga kanthil yang sudah dipersembahkan kepada Panembahan Senopati dan Kanjeng Ratu Kidul.

\footnotetext{
${ }^{8}$ Wawancara dengan Juru Kunci; Oktober 2016
}

Kuncup bunga kanthil dipercaya dapat mengusir roh-roh jahat. Ibu Sutinah percaya bahwa suaminya sedang terkena gendam pelet dan kuncup bunga kanthil dapat menghilangkan pengaruh jahat dari ajian tersebut sehingga suaminya sadar dan kembali kepadanya. Kuncup bunga kanthil tidak hanya untuk menghilangkan pengaruh jahat dari roh-roh jahat (menolak bala), akan tetapi juga dapat mendatangkan berkat pelarisan. Seperti yang dilakukan oleh bapak Sunarto, ia senantiasa mengantongi kuncup bunga kanthil yang diambilnya dari perziarahan di Parangkusuma ketika ia sedang melaksanakan transaksi jual beli sapi.

Kuncup bunga kanthil sebagai simbol dari kekuatan yang ada pada tokoh mitos yang pada akhirnya kekuatan tersebut memampukan seseorang untuk dapat mewujudkan permohonannya. Kehadiran tokoh mitos (daya dari tokoh mitos) diwujudkan dalam kuncup bunga yang dipercaya dapat mengubah "takdir" pada dirinya.

\section{Pembakaran Dupa dan Kemenyan}

Dalam tradisi agama-agama, untuk menyampaikan persembahan kepada yang Illahi dengan cara membakar persembahan tersebut. Bau harum yang tercium dan asap yang membubung ke langit dipercaya bahwa persembahannya telah tercium dan 
sampai kepada alamat yang dituju, yaitu para dewa di angkasa. Dalam upacara labuhan dan ziarah di Parangkusuma, para juru kunci sebelum memanjatkan apa yang menjadi permohonannya senantiasa diawali dengan membakar dupa ratus atau kemenyan. Seiring dengan terbakarnya ratus dan wewangian yang dikeluarkan, juru kunci memanjatkan doa kepada Allah melalui Panembahan Senopati dan Kanjeng Ratu Kidul.

Di samping itu, pembakaran dupa juga sebagai lambang kehadiran dari para dewa untuk menerima permohonan dari para hambanya. Kehadiran para dewa (Kanjeng Ratu Kidul dan Panembahan Senopati) dipahami melalui asap dupa yang dibakar. Demikian juga dengan bunga persembahan itu disampaikan kepada para dewa dan diterima, sehingga ada perbedaan keberadaan kuncup bunga kanthil yang sudah dipersembahkan dengan yang belum dipersembahkan (dalam kasus kuncup bunga kanthil).

Dalam pemahaman Jawa, kehadiran dari dewa (dalam hal ini Kanjeng Ratu Kidul) adalah kehadiran untuk memberikan anugerah kepadanya berupa perwujudan permohonannya. Dengan pembakaran dupa, sebagai simbol kehadiran dari Kanjeng Ratu Kidul dan atas perkenannya hadir berarti Kanjeng Ratu Kidul berkenan memberikan anugerah. Wangi asap dupa yang mengepul juga sebagai lambang doa yang dihantarkan kepada Kanjeng Ratu Kidul dan Panembahan Senopati, baik yang dibakar di pantai ataupun di cepuri oleh juru kunci demikian juga hio yang dibakar di tepi pantai untuk memohon langsung kepada Kanjeng Ratu Kidul.

\section{Sikap Tubuh dalam Berdoa}

Setelah menghadap juru kunci dan bunga persembahan didoakan, peziarah lalu bersimpuh di hadapan selo gilang. Ketika peziarah berjalan menuju selo gilang, setelah sampai ia duduk bersila dan kemudian tangan menyembah pada selo gilang dengan kepala sedikit menunduk. Demikian juga ketika menuju ke pantai Parangkusuma, biasanya mereka berjalan sampai batas ombak dan kemudian duduk bersila dan tangan menyembah.

Orang Jawa mengenal posisi duduk yang demikian ini jikalau mereka dating menghadap kepada pembesar istana. Setelah memberikan sembah, para peziarah kemudian hening sejenak dan dalam saat hening ini ada di antara para peziarah yang membaca surat Al-Fatihah dan dilanjutkan mengatakan apa yang menjadi maksud dan tujuannya dating menghadap Kanjeng Ratu Kidul dan Panembahan Senopati. Pantai Parangkusuma dipercaya sebagai pintu gerbang masuk ke istana Kanjeng Ratu Kidul. Sikap tubuh seseorang di dalam 
menghadap (pisowanan) dipercaya menentukan terkabul atau tidaknya suatu permohonan karena sikap hormatnya kepada Kanjeng Ratu Kidul dan Panembahan Senopati.

\section{Air Laut}

Peninggalan-peninggalan dari para kekasih Allah atau dari tokoh mitos dipercaya mempunyai kekuatan magis tertentu yang dapat menolongnya mewujudkan cita-cita. Demikian juga dengan air laut di pantai Parangkusuma dipercaya mempunyai daya magis tertentu. Air laut sebagai bagian dari keraton Kanjeng Ratu Kidul dan oleh karenanya daya magis yang ada pada Kanjeng Ratu Kidul juga melekat pada air laut. Air dalam pemahaman Jawa mempunyai sifat menyucikan. Air laut yang diambil dari Pantai Parangkusuma dipercaya tidak hanya memberikan berkat padanya, akan tetapi juga memberikan perlindungan dari mara bahaya termasuk dari lawan bisnisnya/saingannya.

\section{Selasa dan Jumat Kliwon}

Perziarahan dilakukan pada setiap Selasa Kliwon dan Jumat Kliwon. Periode ini akan terulang setiap 35 hari sekali (selapan). Meskipun Selasa dan Jumat Kliwon bukan hari yang bernilai tinggi, akan tetapi keberadaan hari Selasa dan Jumat Kliwon dihubungkan dengan keberadaan lelembut (roh-roh halus) di mana pada hari-hari tersebut, para roh halus keluar ke dunia manusia termasuk Kanjeng Ratu Kidul.

Hari Selasa Kliwon disebut juga dengan Anggara Kasih (anggara = Selasa), di mana pemahaman orang Jawa tentang hari tersebut adalah hari yang baik untuk melakukan kegiatan-kegiatan. Nilai kesakralan Jumat Kliwon (khususnya malam Jumat Kliwon) ialah karena pada saat itu dipercaya sebagai malam di mana para roh-roh halus keluar untuk mencari "makan". Oleh karena itu setiap malem Jumat Kliwon orang Jawa melakukan "wungon" supaya terhindar dari gangguan para roh-roh jahat. Akan tetapi, malam Jumat Kliwon menjadi malam yang baik karena pada saat itu manusia lebih mudah berhubungan dengan roh-roh halus yang dipercaya dapat membantu dan mengabulkan segala permohonannya. Perziarahan pada Jumat Kliwon adalah hari yang tepat karena pada saat itu Kanjeng Ratu Kidul berkenan hadir dan kehadirannya berkenan memberikan berkat bagi orang-orang yang memohon kepadanya.

\section{Ratu Kidul}

Twikromo mengatakan bahwa secara tehnis antropologis, mitos Kanjeng Ratu Kidul dipandang sebagai cultural universal 
yang didukung oleh beberapa cultural activities, seperti upacara labuhan, cerita rakyat atau kisah Panembahan Senopati, kegiatan sosial-keagamaan tertentu. Keberadaan seorang raja (sultan) senantiasa dihubungkan dengan penguasa-penguasa alam supranatural dalam hal ini Kanjeng Ratu Kidul. Kekuasaan Kanjeng Ratu Kidul bersifat mutlak, karena Kanjeng Ratu Kidul dianggap sebagai wakil Yang Illahi (utusan Pangeran) yang menguasai dan membawahi makhluk halus Laut Selatan. Terhubungnya Kanjeng Ratu Kidul dengan Keraton Yogyakarta karena ia dipandang sebagai pelindung keraton yang terjalin sejak Panembahan Senopati. Demikian juga dengan banyak orang, percaya bahwa Kanjeng Ratu Kidul dapat memberikan berkat keselamatan bagi kehidupannya.

Upacara labuhan dilakukan untuk menghormati dan memberikan persembahan kepada Kanjeng Ratu Kidul. Hal ini dilakukan untuk mengingat akan perjanjian antara Panembahan Senopati dan keturunannya dengan Kanjeng Ratu Kidul atas perlindungan bagi Keraton Yogyakarta. Demikian juga praktek-praktek keagamaan (ziarah) yang dilakukan oleh masyarakat merupakan tindakan permohonan akan perlindungan dan berkat bagi keselamatan dan kehidupannya.

Hubungan yang terjalin antara Kanjeng Ratu Kidul dengan "kawula alit" (masyarakat Jawa) sebagai "kawula" (rakyat) dari keraton Yogyakarta. Penyelenggaraan upacara labuhan bagi keraton Yogyakarta pada saat ini diselenggarakan pada setiap tanggal 27 bulan Rejeb (menurut kalender Jawa). Pemilihan tanggal pelaksanaan upacara labuhan biasanya didasarkan atas hari kelahiran (untuk labuhan alit/kecil) dan tanggal penobatan menjadi raja (untuk labuhan ageng/besar). Atas dasar pemilihan tanggal ini, dapat dilihat keterikatan antara Sri Sultan (sebagai penguasa keraton Yogyakarta) dengan keberadaan Kanjeng Ratu Kidul.

Letak keraton Yogyakarta yang menjadi pusat di antara empat kerajaan mistis, yaitu di Selatan adalah Keraton Kidul (tempat dari Kanjeng Ratu Kidul), di utara adalah Keraton Merapi (Gunung Merapi, tempat dari Kanjeng Ratu Sekar Kedaton dan Kyai Sapujagad), di sebelah Timur adalah Keraton Lawu (Gunung Lawu tempat dari Kanjeng Sunan Lawu) dan di sebelah Barat adalah Kahyangan Dlepih (tempat dari Sang Hyang Pramoni). Keraton Yogyakarta berada di tengah-tengah empat kerajaan mistis di atas menunjukkan adanya pemahaman bahwa keraton Yogyakarta keberadaannya sangat bergantung pada hubungan di antara kerajaan-kerajaan mistis tersebut. 
Yang menarik adalah di antara keempat kerajaan mistis tersebut, Kanjeng Ratu Kidul (Keraton Segara Kidul) menduduki posisi yang penting di dalam hubungan di antara keduanya. Hubungan ini menjadi penting karena keberadaan tokoh Kanjeng Ratu Kidul dengan Panembahan Senopati dan keturunannya tidak hanya sebatas yang saling membantu, akan tetapi juga sebagai suami istri. Hubungan antara Kanjeng Ratu Kidul dengan para raja di keraton Yogyakarta, dapat digambarkan/simbolisasi hubungan raja dengan samudra yang menggambarkan keberadaan rakyatnya yang senantiasa bergelombang seperti halnya lautan.

Tokoh mitos Kanjeng Ratu Kidul menjadi populer di antara masyarakat Jawa (Keraton Yogyakarta) dan terhubung dengan tokoh Panembahan Senopati di mana Kanjeng Ratu Kidul sebagai penguasa Laut Selatan senantiasa memberikan pertolongan dan perlindungan bagi mereka yang memohon kepadanya seperti halnya yang dilakukan dan dialami oleh keraton Yogyakarta. Kanjeng Ratu Kidul sebagai pusat dari aktivitas keagamaan yang ada di upacara labuhan dan peziarahan di Parangkusuma sudah menjadi bagian dari kehidupan mitos orang Jawa, khususnya Jawa Tengah. Dalam upacara labuhan dan perziarahan yang ada di pantai Parangkusuma, keberadaan Kanjeng Ratu
Kidul menempati posisi sentral. Kanjeng Ratu Kidul ditempatkan sebagai pusat dari obyek penyembahan.

Sebagai bagian dari mitos orang Jawa, penyembahan terhadap Kanjeng Ratu Kidul berdasarkan pemahaman Jawa (Kejawen), meskipun demikian juga terdapat unsurunsur Islam di dalamnya. Walaupun terdapat unsur-unsur Islam, yang terjadi bukanlah sebuah percampuran dan membentuk sebuah pemahaman yang baru, melainkan dua hal yang berbeda (unsur Islam dan Kejawen) tetap pada pemahamannya masing-masing dan pemahaman itu berpusat pada sosok mitos Kanjeng Ratu Kidul yang dapat diterima oleh keduanya.

\section{KESIMPULAN}

Upacara labuhan dan perziarahan yang terjadi di Parangkusuma memperlihatkan adanya dua buah unsur yang membentuknya, yaitu Hindu (Kejawen) dan Islam. Pertemuan dua buah tradisi ini tidak membentuk sebuah tradisi yang baru (sinkretisme ataupun sintesa), walaupun keduanya memiliki kesamaan yang berpusat pada tokoh mitos Kanjeng Ratu Kidul, yang daianggap sebagai perantara berkah yang diminta oleh manusia. Pemahaman di antara keduanya tetap pada jalurnya masingmasing, sehingga yang terjadi di Parangkusuma adalah sebuah parallelisme 
antara Islam dan Kejawen. Parallelisme yang terjadi di Parangkusuma antara Islam dan Kejawen merupakan titik temu pada tokoh mitos Kanjeng Ratu Kidul, yang dinampakkan dalam tindakan dari para pelaku tradisi di Parangkusuma.

\section{Implikasi}

Bangsa Indonesia yang terdiri dari multi etnis, agama dan budaya adalah sebuah kekayaan tersendiri sebagai anugerah Tuhan. Akan tetapi kekayaan tersebut juga mengandung sebuah ancaman disintegrasi bagi kesatuan yang ada. Dalam kehidupan beragama terjadi kebangkitan keberagaman di Indonesia. Sikap fanatisme agama semakin tinggi. Orang-orang semakin sadar akan kehidupan beragamanya. Perbedaan kepentingan dalam agama seringkali muncul dan menimbulkan berbagai konflik.

Persebaran masyarakat Jawa yang terlihat hampir merata di seluruh Indonesia, telah menjadikan masyarakat ini sebagai bagian yang turut menentukan keberadaan Indonesia. Pandangan tentang keharmonian/ keselarasan yang ada pada masyarakat Jawa adalah aset yang dapat menjaga keutuhan persatuan dan kesatuan bangsa Indonesia, di mana konflik dikelola dalam sebuah keselarasan. Penerimaan atas sesuatu yang asing untuk menjadi bagian dari miliknya dengan prinsip keharmonian dan keselarasan dapat memperkecil konflik yang terjadi. Penerimaan sesuatu yang berbeda dengan dirinya tidaklah senantiasa dengan mengambil dan mencampurkannya dengan apa yang dimilikinya melainkan dapat juga dengan menerima dan membiarkannya berjalan sebagaimana mestinya (parallel), seiring dengan apa yang sudah ada atau yang dipahaminya.

Sikap parallelisme juga berarti sebuah sikap yang menerima sesuatu yang berbeda dari dirinya dan penerimaan itu dengan menghargai keberbedaan sebagai sesuatu yang parallel serta berjalan bersama-sama. Perjalanan dalam parallelisme dapat bertemu pada sebuah kepentingan yang sama dengan tanpa mencampuradukkan keduanya misalnya kepentingan akan keadilan yang diusahakan secara bersamasama menurut pemahamannya masingmasing dalam usaha menuju keadilan yang sesungguhnya. Seperti halnya yang terjadi di Parangkusuma, terjadi dua buah pemahaman yang berbeda antara Islam dan Kejawen, akan tetapi keduanya dapat diterima sebagai bagian dari miliknya dan pertemuan itu tercipta pada sebuah tokoh mitos Kanjeng Ratu Kidul.

Apa yang terjadi pada bangsa Indonesia saat ini adalah penghargaan serta penerimaan atas sesuatu yang berbeda menjadi bagian dari miliknya serta "bertemu" dalam mewujudkan suatu tujuan 
yang lebih besar dan mulia. Meskipun pada akhirnya masing-masing berjalan pada relnya sendiri-sendiri, akan tetapi tetap dalam kerangka tujuan yang sama, dan oleh karena itu dicari sebuah titik pertemuan yang dapat mengikatnya dalam sebuah kesatuan. Titik pertemuan itu adalah sebuah kepentingan bersama bangsa Indonesia yang dipahami secara bersama-sama demi kemajuan dan kesejahteraan bersama. Dalam bidang kehidupan keberagaman, sikap parallelisme dapat digunakan sebagai salah satu yang memampukan bangsa ini untuk menghargai keberbedaan dalam sebuah kesejajaran untuk kesejahteraan bersama sebagai titik temunya.

\section{DAFTAR PUSTAKA}

Geertz, Clifford. Abangan, Santri Dan Priyayi Dalam Masyarakat Jawa. Jakarta: Pustaka Jaya, 1981.

Soetapa, Djaka, ed. Lima Titik Temu Agama-Agama. Yogyakarta: Duta Wacana University Press, 2000.

Supajar, Damarjati. Kedudukan "Laku” Dalam Rangka Pandangan Hidup Orang Jawa. Yogyakarta: Yayasan Ilmu Pengetahuan dan Kebudayaan Panunggalan, 1998.

Twikromo, Y. Argo. Ratu Kidul.

Yogyakarta: Yayasan Bentang Budaya, 2000.

Woodward, Mark. Islam Jawa. Yogyakarta: LKIS, 1989. 